\title{
Practical Implications of Management Accounting Information: A Personal Journey
}

\author{
Submitted 01/09/19, 1st revision 28/09/19, $2^{\text {nd }}$ revision $26 / 10 / 19$, accepted 10/11/19
}

\author{
Joy Lynn R. Legaspi ${ }^{1}$
}

\begin{abstract}
:
Purpose: This study focused on the usefulness of management accounting information to small-medium-sized service enterprises other than manufacturing business. The size and industry classification are important proxies among firms to have market concentration.

Design/Methodology/Approach: Median, Spearman Rho, Mann-Whitney U Test, KruskalWallis, and post Hoc test were used to analyzed the relationship of variables and test of difference between and among the service activities based on the data surveyed from 180 respondents.
\end{abstract}

Findings: The evidence suggests that statement of cash flow analysis, capital budgeting decisions, financial budgets, and managing customers' relationship are the very useful management accounting tools enough to response for their urgent needs to operate and grow. There is always non-uniformity of accounting techniques because of the industry classification, enterprise size, the nature of their operation, different managers interpretations placed on particular tool and the knowledge and skills in adopting accounting methods make comparison difficult. Therefore, the choices are associated on the particular problem at hand and the potential problems in the future.

Practical Implications: To provide for more valuable representation about the usefulness of management accounting information this time across SMEs service activities. This is because previous research findings has focused more on large and private industries and the current research investigated mostly on small-medium-sized manufacturing activities.

Originality/Value: Surveyed accommodation and food service activities, financial and insurance activities, and professional, scientific and technical activities in the research design to give importance and be certain to evaluate the level of its usefulness, test the relationship of net income and capital on the level of usefulness of MATs used, test the difference of the level of usefulness between and across SMEs and identify the problems encountered in the application of management accounting tools used as techniques across service business type of activities.

Keywords: Business sector, management accounting, manufacturing, service, small-mediumsized enterprises.

JEL Codes: M40, M41.

Article Type: Research study.

\footnotetext{
${ }^{1}$ Associate Professor, Department of Accountancy, De La Salle University-Manila, happylegaspi@gmail.com
} 


\section{Introduction}

In today's financial system, small-medium-sized enterprises (SMEs) represent a major business sector in the industrial world and of great significance to the Philippines' economy. SMEs contributed almost $32.10 \%$ or 2,499,236 jobs to help reduce poverty despite the unstable global environment. Majority of the SMEs in operation as per Department of Trade and Industry (DTI) declaration are in the accommodation and food service activities with 13,940, followed by financial and insurance activities with 6,113, and professional, scientific and technical activities with 2,008 business establishments (DTI, 2015). This research is a continuation of the previous studies made by Legaspi (2018) about the gap mentioned by Scapens (2006) that the development and implementation of management accounting and systems were developed mostly in central economies but are not fully used in developing countries particularly the SMEs.

In terms of employment, MSMEs generated a total of 4,784,870 jobs in 2015 versus 2,981,819 for large enterprises. This indicates that MSMEs contribute almost $61.6 \%$ of the total jobs generated by all types of business establishments on that year. Of these, $29.4 \%$ or $2,285,634$ jobs were generated by micro enterprise; $25.3 \%$ or $1,968,452$ by small enterprises; and $6.8 \%$ or 530,784 by medium enterprises (DTI, 2015). Therefore the evidence suggests that SMEs is expanding, their markets and the range of necessary information becomes dynamic. Given the importance of increasing need for enterprises to operate economically, management accounting has probably plays an important role in discovering, improving and sustaining the quality of planning, controlling the business operations, decision making and performance evaluation (Garrison et al., 2015). This is to ensure that the Philippines' economy moves forward to create more opportunities, employment, and stable income distribution.

\section{Literature Review}

Shields (1997), Foster and Young (1997), Luft and Shield (2003), Carter (2007), Hilton (2008), Weygandt et al. (2008), Atkinson et al. (2012), Horngren et al. (2015), and Garrison et al. (2015) are the best and well known management accounting textbook authors and researchers that provide substantive contribution to knowledge. All of them shared similar and promising concepts of giving ideas to owners, general managers, finance/accounting managers, accountants and other interested users. It was about the extent on how management accounting information can help them to perform their functions and be aware of latest issues that takes place in business around the world (as cited in Legaspi, 2014).

However, Scapens (2006) discovered that the ideas about the use of management accounting information into practice has focused mainly in large private and public organization (as cited in Legaspi, 2018). Scapens (2006) was concerned on how this management accounting information could helped the SMEs managers to do their 
jobs better. Therefore, researchers like Nandan (2010) of Australia, Uyar (2010) of Turkey, Lucas et al. (2013) of United Kingdom (2013), Sunarni (2013) of Indonesia, and Legaspi (2018) of Philippines were inspired to do descriptive and explanatory studies to further and extend the investigations on the usefulness of management accounting information among SMEs.

Nandan (2010) discovered that owner-managers do not have the knowledge and expertise to apply the traditional and the modern management accounting information as tools to face and handle complex management issues. Then, based on the eleven (11) mixed SME owner-managers interviewed by Lucas et al. (2013), traditional management accounting tools such as product or service cost, break-even analysis and working capital measure were enough for them to make decisions without much management accounting information. Even though Uyar (2010) designed to test it using 61 randomly chosen small, medium and large manufacturing companies, the outcomes remained unsatisfactory. The budget for planning and control system perceived as the most important traditional tool to perform their tasks. However, when Sunarni (2013) studied the 30 medium-scale companies, total quality management, standard costing and variance analysis surprisingly ranked as part of the top-three most important tools other than the use of budgeting (as cited in Legaspi, 2018).

Legaspi (2018) carefully designed her study by way of calculating the median score for each level of usefulness of MATs used, then test the relationship and difference of the selected variables through an equal number of respondents, 30 small and 30 medium manufacturing enterprises. Legaspi (2018) revealed that capital budgeting and financial budget benefited most of the medium manufacturing sector. While, small manufacturing sector focused much of their attention on how they can provide adequate cash balance to meet their daily needs through the use of cash flow analysis.

Then, her study found out a strong significant positive relationship between the net income and the usefulness of MATs and between capital and the usefulness of MATs for medium sector only. Legaspi (2018) concluded that the utilization of the MATs was the same but differ into the level of usefulness due to the choices in choosing which of the tools is necessary to conduct their business operations and which is not. Additionally, based on her study, all SMEs agreed that in support of their very useful tools, product cost, operating budgets, financial statement analysis, and managing customers' relationship were actively used too, to help them accomplish their strategic and tactical goals. Both group believed that the use of other MATs are not deemed necessary due to the nature and sized of the enterprise operations.

\section{Methodology}

\subsection{Research Design}


The requirement of the research objectives allows the researchers to use descriptive and explanatory study and carried it out cross-activity analysis (Blumberg et al., 2014) . The design helped the researchers to generate some statistics to draw powerful inferences. Survey was conducted through mail, e-mail, and telephone interview to ask the opinion and knowledge of the selected respondents using closed ended questions (Likert-scale and check-a-box type of answers). Exactly the same survey questionnaire used by Legaspi 2018 was adapted in this study.

\subsection{Sampling Procedure}

The 180 respondents of SMEs were gathered from the combination of judgmental and quota samples (Cooper and Schindler, 2014) to conform in studying selected types of subjects such as: accommodation and food service activities (30), financial and insurance activities (30), and professional, scientific and technical activities (30). The place and the address of the owners, general managers, finance/accounting managers and accountant surveyed were found from the list of establishments given by the Security and Exchange Commission (SEC, 2018) per business sector in the National Capital Region (NCR) and the Department of Industry (DTI, 2015) per city. The classification of industries whether small (10-99) or medium (100-199) varies according to the number of employees (SEC, 2018). It was the most widely used indicator whether the respondents belong to small or medium enterprises in the Philippines (DTI, 2015).

\subsection{Reliability of a Scale}

The reliability of the scale in every research question varies depending on the type of the particular sample. Cronbach alpha is one of the most commonly used to test internal consistency. Values above .8 are preferable, however, values above 0.7 are considered acceptable (DeVellis, 2012 and Pallant, 2000).

Table 1. Reliability Statistics

\begin{tabular}{l|l|l}
\hline Cronbach's Alpha & $\begin{array}{l}\text { Cronbach's Alpha Based on } \\
\text { Standardized Items }\end{array}$ & N of Items \\
\hline 0.791 & 0.774 & 20 \\
\hline
\end{tabular}

Table 1 illustrates the reliability statistics, the Cronbach alpha coefficient is 0.791 , suggesting good internal consistency reliability for the scale with this sample.

\subsection{Statistical Treatment of Data}

The researcher obtained descriptive statistics for categorical variables using the median to tell how many people gave each response as to the level of usefulness of MATs used (Tabachnick and Fidell, 2013). Spearman rho was designed with ordinal level to obtain strength and direction of the relationship between the net income and capital to the level of usefulness of MATs used. Cohen (1988) suggests the 
following guidelines to interpret the values between 0 and 1 : small $\mathrm{r}=0.10$ to 0.29 ; medium $r=0.30$ to 0.49 ; and large $r=0.50$ to 1.0. for the findings of the samples.

The Mann-Whitney U Test was used to evaluate whether ranks for the small and medium groups differ significantly. The direction of the difference in which group is higher was determined from the mean rank for small and medium groups. To compare the score for three groups such as: accommodation and food service activities, financial and insurance activities, and professional, scientific and technical activities, Kruskal-Wall Test was introduced (Tabachnick and Fidell, 2013). To control for the Type1 error, it is recommended to apply Post-hoc Test "IF" statistically significant difference to compare each group to one another is obtained . A Bonferroni adjustment is intended to use for determining significant difference (Steven, 1996; Tabachnick and Fidell, 2013) on the study.

\section{Findings and Discussions}

The output in Table 2 gives you a quick summary of the level of usefulness of MATs used by small enterprises. We know that six (6) MATs provide practical use out of the 20 tools set out. Statement of cashflow (4) in the sample is the "very useful" tool whereas, capital budgeting decisions (3), financial budgets (3), financial statement analysis (3), managing customers' relationship (3) and operating budgets (3) turns out to be "useful" tools utilized by 90 respondents of small enterprises.

Table 2. The level of Usefulness of MATs Used by Small Enterprises

\begin{tabular}{ll|l}
\hline Management Accounting Tools & Median & VI \\
\hline Statement of cash flow analysis & 4 & VU \\
\hline Capital budgeting decisions & 3 & $\mathrm{U}$ \\
\hline Financial budgets & 3 & $\mathrm{U}$ \\
\hline Financial statement analysis & 3 & $\mathrm{U}$ \\
\hline Managing customers' relationship & 3 & $\mathrm{U}$ \\
\hline Operating budgets & 3 & $\mathrm{U}$ \\
\hline Benchmarking & 2 & $\mathrm{LU}$ \\
\hline Cost-volume-profit analysis & 2 & $\mathrm{LU}$ \\
\hline Product or service cost information & 2 & $\mathrm{LU}$ \\
\hline Relevant costs for decision making & 2 & $\mathrm{LU}$ \\
\hline Total quality management & 2 & $\mathrm{LU}$ \\
\hline Activity-based costing & 1 & $\mathrm{NU}$ \\
\hline Balance scorecard & 1 & $\mathrm{NU}$ \\
\hline Just-in-time & 1 & $\mathrm{NU}$ \\
\hline Kaizen costing & 1 & $\mathrm{NU}$ \\
\hline Lean manufacturing & 1 & $\mathrm{NU}$ \\
\hline Responsibility accounting & 1 & $\mathrm{NU}$ \\
\hline Stand costing and variance analysis & 1 & $\mathrm{NU}$ \\
\hline
\end{tabular}




\begin{tabular}{|c|c|c|}
\hline Target costing for product planning & 1 & NU \\
\hline Transfer pricing & 1 & NU \\
\hline
\end{tabular}

The result presented in Table 3 suggests that nine (9) MATs provide practical use out of the 20 tools set out. There are more "very useful" tools used for medium enterprises such as: capital budgeting decisions (4), financial budgets (4) and managing customers' relationship (4). In the given sample, 90 of the medium respondents considered financial statement analysis (3), operating budgets (3), product or service cost information (3), statement of cash flow analysis, relevant costs for decision making (3) and total quality management (3) considered as the "useful" tools to run their businesses.

Table 3. The level of Usefulness of MATs Used by Medium Enterprises

\begin{tabular}{ll|l}
\hline Management Accounting Tools & Median & VI \\
\hline Capital budgeting decision & 4 & VU \\
\hline Financial budgets & 4 & VU \\
\hline Managing customers' relationship & 4 & VU \\
\hline Financial statement analysis & 3 & $\mathrm{U}$ \\
\hline Operating budgets & 3 & $\mathrm{U}$ \\
\hline Product or service cost information & 3 & $\mathrm{U}$ \\
\hline Statement of cash flow analysis & 3 & $\mathrm{U}$ \\
\hline Relevant costs for decision making & 3 & $\mathrm{U}$ \\
\hline Total quality management & 3 & $\mathrm{U}$ \\
\hline Standard costing and variance analysis & 2 & $\mathrm{LU}$ \\
\hline Activity-based costing & 2 & $\mathrm{LU}$ \\
\hline Benchmarking & 2 & $\mathrm{LU}$ \\
\hline Cost-volume-profit analysis & 2 & $\mathrm{LU}$ \\
\hline Target costing for product planning & 2 & $\mathrm{LU}$ \\
\hline Balance scorecard & 2 & $\mathrm{LU}$ \\
\hline Just-in-time & 1 & $\mathrm{NU}$ \\
\hline Kaizen costing & 1 & $\mathrm{NU}$ \\
\hline Lean manufacturing & 1 & NU \\
\hline Responsibility accounting & 1 & NU \\
\hline Transfer pricing & 1 & NU \\
\hline Verbal Interpretation (VI): $1=$ Not Useful; 2 = Less Useful; $3=$ Useful; 4 = Very Useful \\
\hline & & \\
\hline
\end{tabular}

The relationship between the level of net income and the level of usefulness of MATs used as perceived by owners, general managers, finance/accounting managers, and accountants of small enterprises was investigated using Spearman rho correlation coefficient as presented in Table 4 . There is a strong positive correlation between the two variables, rho $=0.513, \mathrm{n}=90, \mathrm{p}<0.01$, with high levels of net income associate with high levels MATs used. On the other hand, there is a weak positive correlation between the two variables, rho $=0.203, \mathrm{n}=90, \mathrm{p}>0.05$, 
indicating that there are many exceptions to the trend or movement because of its weak relationship for medium enterprises. The result explained by pure chance and the data are not significant.

Table 4. Correlation Analysis Between the Level of Net Income and the Level of Usefulness of MATs Used by SMEs

\begin{tabular}{|c|c|c|c|c|c|c|}
\hline & & & SEs & $\begin{array}{l}\text { Net } \\
\text { Income of } \\
\text { SEs }\end{array}$ & MEs & $\begin{array}{l}\text { Net } \\
\text { Income } \\
\text { of MEs }\end{array}$ \\
\hline \multirow[t]{6}{*}{$\begin{array}{l}\text { Spearman's } \\
\text { rho }\end{array}$} & \multirow{3}{*}{$\begin{array}{l}\text { Level of } \\
\text { Usefulness } \\
\text { of MATs } \\
\text { Used by } \\
\text { SMEs }\end{array}$} & $\begin{array}{l}\text { Correlation } \\
\text { Coefficient }\end{array}$ & 1.000 & $.513^{* *}$ & 1.000 & 0.203 \\
\hline & & Sig. (2-tailed) & & 0.000 & & 0.054 \\
\hline & & $\mathrm{N}$ & 90 & 90 & 90 & 90 \\
\hline & \multirow{3}{*}{$\begin{array}{l}\text { Level of } \\
\text { Net Income } \\
\text { of SMEs }\end{array}$} & $\begin{array}{l}\text { Correlation } \\
\text { Coefficient }\end{array}$ & $.513^{* *}$ & 1.000 & 0.203 & 1.000 \\
\hline & & Sig. (2-tailed) & 0.000 & & 0.054 & \\
\hline & & $\mathrm{N}$ & 90 & 90 & 90 & 90 \\
\hline
\end{tabular}

Note: ** Correlation is significant at the 0.01 level (2-tailed).

The relationship between level of capital and the level of usefulness of MATs used as perceived by owners, general managers, finance/accounting managers, and accountants of small enterprises was investigated using Spearman rho correlation coefficient as presented in Table 5. There is a weak positive correlation between the two variables, rho $=0.006, \mathrm{n}=90, \mathrm{p}>0.05$, indicating that that there are many exceptions to the trend or movement because of its weak relationship for small enterprises. However, there is a small positive correlations between the two variables, rho $=0.262, \mathrm{n}=90, \mathrm{p}<0.05$, suggesting that as the level of capital goes up so with the level of usefulness of MATs used for medium enterprises.

Table 5. Correlation Analysis Between the Level of Capital and the Level of Usefulness of MATs Used by SMEs

\begin{tabular}{|c|c|c|c|c|c|c|}
\hline & & & SEs & $\begin{array}{l}\text { Capital } \\
\text { of SEs }\end{array}$ & MEs & $\begin{array}{l}\text { Capital } \\
\text { of MEs }\end{array}$ \\
\hline \multirow[t]{6}{*}{$\begin{array}{l}\text { Spearman } \\
\text { 's rho }\end{array}$} & \multirow{3}{*}{$\begin{array}{l}\text { Level of } \\
\text { Usefulness } \\
\text { of MATs } \\
\text { Used by } \\
\text { SMEs }\end{array}$} & $\begin{array}{l}\text { Correlation } \\
\text { Coefficient }\end{array}$ & 1.000 & 0.006 & 1.000 & $0.262^{*}$ \\
\hline & & Sig. (2-tailed) & & 0.957 & & 0.013 \\
\hline & & $\mathrm{N}$ & 90 & 90 & 90 & 90 \\
\hline & \multirow{3}{*}{$\begin{array}{l}\text { Level of } \\
\text { Capital of } \\
\text { SMEs }\end{array}$} & $\begin{array}{l}\text { Correlation } \\
\text { Coefficient }\end{array}$ & 0.006 & 1.000 & $0.262^{*}$ & 1.000 \\
\hline & & Sig. (2-tailed) & 0.957 & & 0.013 & \\
\hline & & $\mathrm{N}$ & 90 & 90 & 90 & 90 \\
\hline
\end{tabular}

Note: * Correlation is significant at the 0.05 level (2-tailed). 
Table 6 gives you a quick summary of the results of the test of difference between the level of usefulness of MATs used by SMEs, in this case the Sig. value (which is the $\mathrm{p}$ value) is .000 . This is less than 0.05 , therefore the result is significant.

Table 6. Hypothesis Tests Summary - Test of Difference Between SMEs

\begin{tabular}{|c|c|c|c|c|}
\hline & Null Hypothesis & Test & Sig. & Decision \\
\hline 1 & $\begin{array}{l}\text { The distribution of Level of } \\
\text { Usefulness of MATs Used by SMEs } \\
\text { is the same across categories of } \\
\text { Classification of Employee. }\end{array}$ & $\begin{array}{l}\text { Independent- } \\
\text { Samples Mann- } \\
\text { Whitney U Test }\end{array}$ & 0.000 & $\begin{array}{l}\text { Reject the } \\
\text { null } \\
\text { hypothesis. }\end{array}$ \\
\hline
\end{tabular}

Note: Asymptotic significances are displayed. The significance level is .050.

Figure1 describes the direction of the difference between the level of usefulness of MATs used. Medium enterprises (mean rank = 109.59) is significantly higher (0.000) in the level of usefulness of MATs used compared to small enterprises (mean rank $=71.41)$.

Figure 1. Independent-Sample Mann-Whitney U Test Classification of Employee

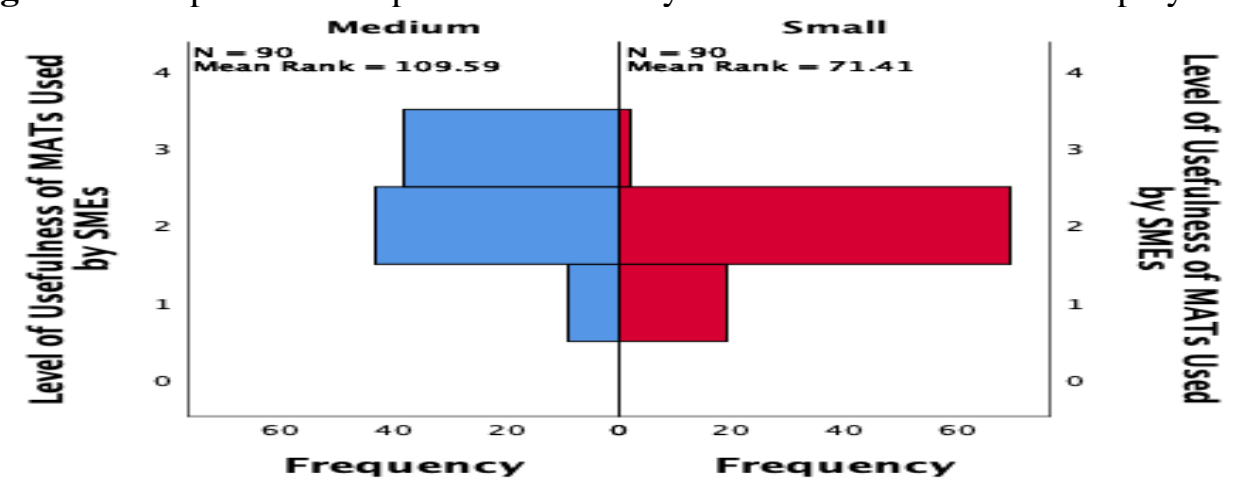

A Mann-Whitney $U$ test as shown in Table 7 revealed significant difference in the level of usefulness of MATs used of medium enterprises (Mean =109.59, n 90) and small enterprises $($ Mean $=71.41, \mathrm{n} 90), \mathrm{U}=5768, \mathrm{Z}=5.597,=0.000$.

Table 7. Independent Samples Mann-Whitney U Test Statistics

\begin{tabular}{ll}
\hline Total N & 180 \\
\hline Mann-Whitney U & 5768.000 \\
\hline Wilcoxon W & 9863.000 \\
\hline Test Statistic & 5768.000 \\
\hline Standard Error & 301.571 \\
\hline Standardized Test Statistic & 5.697 \\
\hline Asymptotic Sig.(2-sided test) & 0.000 \\
\hline
\end{tabular}

Table 8 gives you a quick summary of the results of the test of difference across the level of usefulness of MATs used by Small enterprises, in this case the Sig. value 
(which is the $\mathrm{p}$ value) is 0.821 . This is greater than 0.05 , therefore the result is not significant.

Table 8. Hypothesis Test Summary-Across Small Enterprises

\begin{tabular}{ll|l|l|l}
\hline & Null Hypothesis & Test & Sig. & Decision \\
\hline 1 & $\begin{array}{l}\text { The distribution of Level of Usefulness } \\
\text { of MATs Used by SE is the same } \\
\begin{array}{l}\text { across categories of Business Sector } \\
\text { Small Enterprises. }\end{array}\end{array}$ & $\begin{array}{l}\text { Sndependent- } \\
\text { Samples Kruskal- } \\
\text { Wallis Test }\end{array}$ & 0.821 & $\begin{array}{l}\text { Retain the } \\
\text { null } \\
\text { hypothesis. }\end{array}$ \\
\hline
\end{tabular}

Note: Asymptotic significances are displayed. The significance level is .050.

A Kruskal-Wallis Test revealed a not statistically significant difference in the level of usefulness of MATs used across three different sectors: accommodation and food service activities, financial and insurance activities, and professional, scientific and technical activities, $\mathrm{X}^{2}(2, \mathrm{n}=90)=0.394, \mathrm{p}=0.821$ presented in Table 9 .

Table 9. Independent-Samples Kruskal Wallis Test Summary - Across Small Enterprises

\begin{tabular}{ll}
\hline Total N & 90 \\
\hline Test Statistic & $0.394^{\mathrm{a}, \mathrm{b}}$ \\
\hline Degree Of Freedom & 2 \\
\hline Asymptotic Sig.(2-sided test) & 0.821 \\
\hline
\end{tabular}

Note: a. The test statistic is adjusted for ties.

b. Multiple comparisons are not performed because the overall test does not show significant differences across samples.

Table 10 gives you a quick summary of the results of the test of difference across the level of usefulness of MATs used by medium enterprises, in this case the Sig. value (which is the $\mathrm{p}$ value) is .052 This is greater than 0.05 , therefore the result is not significant.

Table 10. Hypothesis Test Summary - Across Medium Enterprises

\begin{tabular}{ll|l|l|l}
\hline & Null Hypothesis & Test & Sig. & Decision \\
\hline 1 & $\begin{array}{l}\text { The distribution of Level of Usefulness } \\
\text { of MATs Used by SE is the same } \\
\text { across categories of Business Sector } \\
\text { Medium Enterprises. }\end{array}$ & $\begin{array}{l}\text { Independent- } \\
\text { Samples Kruskal- }\end{array}$ & Wallis Test & $\begin{array}{l}\text { Retain the } \\
\text { null } \\
\text { hypothesis. }\end{array}$ \\
\hline
\end{tabular}

Note: Asymptotic significances are displayed. The significance level is .050.

A Kruskal-Wallis Test revealed a not statistically significant difference in the level of usefulness of MATs used across three different sectors: accommodation and food service activities, financial and insurance activities and professional, scientific and technical activities, $\mathrm{X}^{2}(2, \mathrm{n}=90)=.394, \mathrm{p}=0.052$ presented in Table 11 . 
Table 11. Independent-Samples Kruskal Wallis Test Summary - Across Medium Enterprises

\begin{tabular}{ll}
\hline Total N & 90 \\
\hline Test Statistic & $5.925^{\mathrm{a}, \mathrm{b}}$ \\
\hline Degree Of Freedom & 2 \\
\hline Asymptotic Sig.(2-sided test) & 0.052 \\
\hline
\end{tabular}

Note: a. The test statistic is adjusted for ties.

b. Multiple comparisons are not performed because the overall test does not show significant differences across samples.

Table 12 gives you a quick case summary about the difficulties encountered by SMEs in applying MATs. Lack of qualified employee (69), its use are not deemed necessary as to the nature (57) and size (42) of business operation identified as the top three reasons for small group, while medium enterprises considered that its use are not deemed necessary as to the nature (76), size (46) of business operation, and time consuming to implement (34).

Table 12. Case Summary - SMEs

\begin{tabular}{|c|c|c|c|c|}
\hline \multirow[b]{2}{*}{ Difficulties Encountered in Applying the MATs } & \multicolumn{2}{|c|}{ Small } & \multicolumn{2}{|c|}{ Medium } \\
\hline & $\mathrm{N}$ & Sum & $\mathrm{N}$ & Sum \\
\hline Unaware of the potential contribution of its use & 90 & 41 & 90 & 16 \\
\hline Lack of knowledge/understanding of its use & 90 & 33 & 90 & 19 \\
\hline Lack of qualified employee & 90 & 69 & 90 & 4 \\
\hline Expensive to implement & 90 & 14 & 90 & 27 \\
\hline Time consuming to implement & 90 & 13 & 90 & 34 \\
\hline $\begin{array}{l}\text { Its use are not deemed necessary as to the size of the } \\
\text { enterprise operation }\end{array}$ & 90 & 42 & 90 & 46 \\
\hline $\begin{array}{l}\text { Its use are not deemed necessary as to the nature of the } \\
\text { enterprise operation }\end{array}$ & 90 & 57 & 90 & 76 \\
\hline
\end{tabular}

\section{Conclusion}

Presently, medium service sector emphasized more on the use of managing customers' relationship as part of their top three "very useful" MATs compared to the previous study presented by Legaspi (2018) for medium manufacturing sector. Nowadays, due to tight competition in the local and global market and to have longterm sustainable success (from being small to medium to large business), service enterprises gradually converted their strategy and focused into an intense customer mentality (Atkinson et al., 2012). They keep on learning to understand what are the costumers expectations about their services. Customer satisfaction plays a vital role for customers' retention and it is an aid for the businesses to grow more and it can be used for possible development of trusted relationship between them. 
Then, total quality management and relevant cost for decision making are now part of the "useful" MATs for service activities which is "less useful" for manufacturing activity based on Legaspi's (2018) previous findings. Respondents a now implementing business process improvement through a well-defined planned and the application of the new methods over time. The analysis of cost and opportunity is one of the most critical functions of a manager in making a decision in a wide range of situations. Through the effective use of resources and by way of finding the right alternative process they could reduce service time and production cost in order to produce and render high quality product and service. However, the use of standard costing and variance analysis did not favor them. They may not really need the use of it. The help of simple actual or normal costing is enough to value their service. It is not that important to efficiently perform their task.

On the other hand, there is no difference in terms of the "very useful" MATs for small service activities compared to small manufacturing sector. Cash flow statement analysis is still the best and the most essential among the tools. Cash flow is the key determinants of the value of the firm (Gitman and Zutter, 2012). Managers placed more emphasis on cash flows. Sufficient flow of cash is necessary because whether they earn profit or experience loss, they need to meet their obligations as they come due. Unfortunately, product or service cost information did not materialize its usefulness for them unlike in the manufacturing sector it was considered as a "useful" MAT but now it was considered as "less useful" for the former. Companies have costing systems that are either job order or process costing system. Service sector assigned cost to service using job and it is often a single unit, unique and distinct from other customers. It is more easier to determine the cost of the job because it did not require an extensive analysis of collecting and assigning cost to service.

The results of high median scores of statement of cash flow, capital budgeting decisions, financial budgets, financial statement analysis, managing customers' relationship and operating budgets produced significant relationship to the level of net income but not significant into the level of capital for small service enterprises.

While the calculated high median scores of capital budgeting decisions, financial budgets, managing customers' relationship, financial statement analysis, operating budgets, product or service cost information, statement of cash flow analysis, relevant costs for decision making, and total quality management came out with insignificant relationship as to the level of net income but significant into the level of capital for medium service enterprises. The result could help you to understand and reflect the financial benefits of information and how managers rely on the financial information they prepared. It can be based on maximizing the enterprise value or maximizing its profits.

Also, the results of more used of MATs and the high median scores on the level of usefulness of MATs by medium service enterprises produced significant difference 
as compared to small service enterprises. Which is relevant and connected due to the magnitude and volume of their business activities. Today managers actively think better ways to develop and implement strategies by applying more tools as a technique in helping the firm to grow and improve to become competitive.

Managers in the firm regardless of the size and type of business operations and areas of their responsibility be it in accounting, operation, marketing, management, and so forth - bring out the same result. There was no significant difference on the level of usefulness among small group and medium cluster. Managers made the same perception about the impact of management accounting information that make them smarter from the most basic up to very important financial implication of their decisions.

We observed that their responses related to the difficulties in a applying the MATs were based on the practicability or convenience of its use. The respondents believed that the used of MATs should be greater than its cost. The choice of management accounting information tools as a technique should normally depend on the meaning and its usefulness (cost-effective). Most importantly if its use is relevant then it will become interesting to SMEs managers.

\section{References:}

Atkinson, A., Kaplan, R., Matsumura, E. \& Young, M. 2012. Management Accounting: Information for Decision-Making and Strategy Execution, $6^{\text {th }}$ ed. Pearson Education Ltd., England.

Blumberg, D., Cooper, D. \& Schindler, P. 2014. Business Research Methods, $4^{\text {th }}$ Ed. McGraw-Hill.

Carter, W. 2007. Cost Accounting, $14^{\text {th }}$ Ed. Thomson Learning, Singapore, Asia.

Cohen, J.W. 1988. Statistical power analysis for the behavioral sciences, $2^{\text {nd }}$ Ed. Hillsdale, NJ, Lawrence Erlbaum Associates.

Cooper, D. \& Schindler, P. 2014. Business Research Methods, $12^{\text {th }}$ Ed. McGraw-Hill. Department of Trade and Industry Philippines.2015. Entrepreneurs in Metro Manila. Retrieved from http://dtincr.ph/news.php?id=6.

DeVellis, R.F. 2012. Scale development: Theory and applications, $3^{\text {rd }}$ Ed. Thousand Oaks, California, Sage.

Foster, G. \& Young, M. 1997. Frontiers of Management Accounting Research. Journal of Management Accounting Research, 9, 63-77.

Garrison, R., Noreen, E., Brewer, P., Sang Cheng, N. \& Yuen, K. 2015. Managerial Accounting, Asian Global Edition, $2^{\text {nd }}$ Ed. McGraw-Hill Education, Asia.

Gitman, J. \& Zutter, C. 2012. Principles of Managerial Finance, $13^{\text {th }}$ Ed. Pearson Education, South Asia.

Hilton, R. 2008. Managerial Accounting: Creating Value in a Dynamic Business Environment, $7^{\text {th }}$ Ed. McGraw-Hill Education, Asia.

Horngren, C., Datar, S. \& Rajan M. 2015. Cost Accounting: A Managerial Emphasis, $15^{\text {th }}$ Ed. Pearson Education Ltd., Asia Pacific. 
Legaspi, J.L. 2014. The Impact of Management Accounting Literature to Practice: A Study of Management Accounting Concepts in the Philippines Industries. International Journal of Academic Research in Accounting, Finance and Management Sciences, 4, 347-365.

Legaspi, J.L. 2018. Does Management Accounting Information Meet the Needs of SMEs? An Investigation of Its Usefulness from Manufacturing Enterprises. International Journal of Engineering \& Technology, 7(4.1), 57-62, DOI: 10.14419/ijet.v7i4.1.28225.

Lucas, M., Prowle, M. \& Lowth, G. 2013. Management Accounting Practices of UK SmallMedium-Sized Enterprises, Improving SME performance through Management Accounting Education. Journal of Chartered Institute of Management Accountants, 9(4), 1-12.

Luft, J. \& Shields, M. 2003. Mapping Management Accounting: Graphics and Guidelines for Theory-Consistent Empirical Research. Accounting, Organizations and Society, 28, 169-249.

Nandan, R. 2010. Management Accounting Needs of SMEs and the Role of Professional Accountants: A Renewed Research Agenda. Journal of Management Accounting Research, 8(1), 65-67.

Pallant, J. 2000. Development and validation of a scale to measure perceived control of internal states. Journal of Personality Assessment, 75(2), 308-337.

Scapens, R. 2006. Understanding Management Accounting Practices: A Personal Journey. The British Accounting Review, 38(1), 1-30.

Security and Exchange Commission. 2018. List of Sec Registered Corporations within Metro Manila from 2005-2016. SEC i-Register database.

Shields, M. 1997. Research in Management Accounting by North Americans in the 1990s. Journal of Management Accounting Research, 9, 3-61.

Stevens, J. 1996. Applied multivariate statistics for the social sciences, $3^{\text {rd }}$ Ed. Mahwah, NJ, Lawrence Erlbaum.

Sunarni, C. 2013. Management Accounting Practices and the Role of Management Accountant: Evidence from Manufacturing Companies throughout Yogyakarta, Indonesia. Review of Integrative Business \& Economic Research, 2(2), 616-626.

Tabachnick, B.G. \& Fidell, L.S. 2013. Using multivariate statistics, $6^{\text {th }}$ Ed. Pearson Education, Boston.

Weygandt, J., Kimmel, P. \& Kieso, D. 2008. Managerial Accounting, $14^{\text {th }}$ Ed. John Wiley \& Sons Pte Ltd., Asia.

Uyar, A. 2010. Cost and Management Accounting Practices: A Survey of Manufacturing Companies. Eurasian Journal of Business and Economics, 3(6), 113-125. 